\title{
Hubungan Antara Asupan Karbohidrat, Somatotype dan Persen Lemak Tubuh Terhadap Kelincahan Atlet Futsal Laki-Laki Di Kota Bekasi
}

\author{
Fifi Fauzi Taufiq \\ ${ }^{1}$ Universitas Muhammadiyah Prof. Hamka \\ Korespondensi E-mail: fiqifauzytaufiq@gmail.com
}

Submitted: 19 Maret 2021, Revised: 29 Oktober 2021, Accepted: 20 November 2021

\begin{abstract}
The atblete agility predicts the athlete achievement. Agility in futsal atbletes can increase the ability to perform skills such as dribbling, controlling, and kicking the ball. Low agility can affect the athlete's skills during training or competition. One of the factors that influence agility is carbohydrate intake, somatotype and body fat percent. This study aims to determine the relationship between carbohydrate intake, somatotype and percent body fat on the agility of male futsal athletes in the city of Bekasi. In this study, the methodology used was a quantitative approach with a cross-sectional design. The samples were determined using purposive sampling technique, data collection was carried out by measuring agility using the shuttle run technique, carbohydrate intake using a $3 \times 24$ hour recall interview, somatotype using anthropometric measurements and percent body fat using BIA, technical analysis of data between carbobydrate intake, somatotype, percent body fat with agility using the chi-square. The results showed that carbohydrate intake with agility was less than the degree of significance $(p<0.05)$, somaotytpe with agility more than the degree of significance $(p>0.05)$, and the percent of body fat with agility more than the degree of significance $(p>0.05)$.
\end{abstract}

Keywords: Agility, Somatotype, Percent Body Fat, Carbobydrate Intake, Futsal.

\begin{abstract}
ABSTRAK
Kelincahan atlit menentukan prestasi atlit. Kelincahan pada atlet futsal dapat meningkatkan kemampuan untuk melakukan keterampilan seperti menggiring, mengontrol, dan menendang bola. Jika kelincahan rendah dapat mempengaruhi keterampilan atlet saat latihan maupun pertandingan. Salah satu faktoryang mempengaruhi kelincahan ialah asupan karbohidrat, somatotype dan persen lemak tubuh. Penelitian ini bertujuan untuk mengetahui hubungan asupan karbohidrat, somatotype dan persen lemak tubuh terhadap kelincahan atlet futsal laki- laki di kota Bekasi. Dalam penelitian ini metode yang digunakan adalah dengan pendekatan kuantitatif dengan desain cross-sectional. Penentuan sampel yang digunakan adalah teknik purposive sampling dengan jumlah sampel 45 orang. Pengumpulan dilakukan dengan cara pengukuran kelincahan yang menggunakan teknik shuttle run, asupan karbohidrat menggunakan wawancara recall $3 \times 24$ jam, somatotype menggunakan pengukuran antropometri dan persen lemak tubuh menggunakan bioelectrical impedance analysis (BIA). Teknis analisis data antara asupan karbohidrat, somatotype, persen lemak tubuh dengan kelincahan menggunakan chi-square. Hasil penelitian menunjukkan ada hubungan antara asupan karbohidrat dengan kelincahan $(p<0.05)$, tidak ada hubungan antara somatotype dengan kelincahan $(p>0.05)$, dan tidak ada hubungan antara persen lemak tubuh dengan kelincahan $(p>0.05)$.
\end{abstract}

Kata Kunci: Kelincahan, Somatotipe, Lemak, Karbohidrat, Futsal.

\section{Pendahuluan}

Suatu unsur kebugaran jasmani di dalam olahraga futsal yang sangat penting adalah kelincahan. Kelincahan seseorang yang mampu merubah gerak dan posisi tanpa kehilangan keseimbangan dengan cepat, efisien dan dengan tepat menghentikan gerakan. Saatmenggiring bola, atlet futsal harus memiliki kelincahan yang baik karena kelincahan berperan penting dalam mengatur arah gerak tubuh yang tiba- tiba tanpa kehilangan keseimbangan dengan gerakan yang cepat dan tepat. Jika atlet futsal memiliki kelincahan yang tidak baik atau tidak lincah, maka akan berdampak terhadap kemampuan atlet dalam mengecoh lawan dan tidak dapat menggiring bola, hal ini membuat atlet kurang efektif di lapangan dan gerak kaki yang cepat sehingga tidak dapat mencetak gol (1). Untuk meningkatkan kelincahan pada atlet futsal, maka konsumsi karbohidrat perlu diperhatikan. Beberapa cabang olahraga menjelaskan bahwa konsumsi karbohidrat berhubungan dengan kelincahan (2). Karbohidrat menghasilkan glikogen yang dipecah sebagai cadangan energi pertama pada aktivitas intensitas yang tingi. Konsumsi karbohidrat atlet yakni sebesar 60-70\% total energi. Karbohidrat yang dikonsumsi sebagian besar dalam bentuk karbohidrat kompleks, sedangkan sebagian kecil saja $(<10 \%)$ hanya karbohidrat sederhana (3). 
Selain karbohidrat, faktor lain yang perlu dipertimbangkan pada kelincahan atlit adalah somatotype. Somatotype adalah kesesuaian keadaan tubuh seseorang pada suatu cabang olahraga yang sangat menentukan performa fisiknya. Setiap cabang olahraga memiliki somatotype yang spesifik. Atlet dengan somatotype yang sesuai dengan cabang olahraga ternyata sangat berpengaruh pada performa atlet, seperti halnya atletfutsal yang bisa membentuk tingkat kebugaran yang dimiliki atlet (4). Dalam melakukan aktivitas fisik, somatotype dapat meningkatkan tingkat kebugaran yang diperoleh dari intensitas dan frekuensi dalam melakukan aktivitas fisik (5).

Selain konsumsi karbohidrat dan somatotype, persen lemak tubuh juga sangat penting dipertimbangkan dalam menentukan kelincahan atlit. Persen lemak tubuh merupakan jumlah minimum lemak tubuh yang dibutuhkan untuk menunjang kesehatandan aktivitas sehari-hari. Lemak tubuh memiliki beberapa fungsi utama yaitu, membantu menjaga suhu tubuh,menjaga organ-organ tubuh danmenyimpan energi yang dibutuhkan saat tubuh sedang aktif. Persen lemaktubuh yang berlebih dapat membatasi kinerja seseorang yang membutuhkan daya tahan aerobik yang berkepanjangan seperti atlet endurance (6,7). Kelincahan pergerakan atlet akan berkurang jika atlet mempunyai persentase lemak tubuh yang tinggi dan semakin besar nilai endomorphnya. Skillrelated fitness atau kebugaran termasuk kedalam gerakan fisik dalam olahraga yang berkaitan dengan keterampilan (4).

Sejauh ini, masih terbatas pembahasan mengenai hubungan asupan karbohidrat, persen lemak tubuh dan somatotype pada atlet futsal. Oleh karena itu, maka peneliti ingin mengkaji lebih jauh mengenai hubungan asupan karbohidrat, somatotype dan persen lemak tubuh pada atlet futsal laki-laki di Kota Bekasi.

\section{Metode Penelitian}

Metode penelitian ini merupakanpenelitian kuantitatif dengan desain studi cross-sectional. Penelitian dilakukan pada bulan Agustus 2020 di Kota Bekasi. Populasi terjangkau pada penelitian ini adalah atlet futsal laki-laki akademi always futsal yang berjumlah 50 orang yang dilaksanakan di jam dan hari jadwal latihan. Berdasarkan hasil perhitungan, didapat jumlah besar sampel sebanyak 45 orang. Pengambilan sampel dilakukan dengan cara purposivesampling dengan kriteria inklusi yaitu umur 14-18 tahun, terhidrasi dengan baik, terlatih dan mengikuti latihan futsal selama 1 bulan dan bersedia menjadi responden. Data kelincahan menggunakan metode shuttle run, yaitu tes lari dengan panjang lintasan sepanjang 5 meter dan dilakukan secara bolak balik 5 kali, dinyatakan dalam satuan detik (8). Data asupan karbohidrat mengunakan metode wawancara dengan mengunakan 3x24 jam food recall dan dinyatakan dalam satuan gram (9). Data somatotype menggunakan metode pengukuran, yaitu pengukuran berat badan, tinggi badan, tebal lemak tubuh (triceps, subscapular, suprailiac), lebar tulang (bumerus femur), lingkar lengan atas dan data pengukuran tersebut selanjutnya dihitung dengan rumus persamaan Heath-Carter (10). Data persen lemak tubuh diukur dengan alat Bioelectric Impedance Analyzer (BIA) dan dinyatakan dalam satuan \%. Sementara itu, untuk analisis statistik menggunakan analysis univariat dan bivariat. Analisis univariat untuk melihat karakteristik secara umum dari atlet. Sementara untuk analisis bivariat menggunakan uji chi-square. Hasil penelitian signifikan jika $p$-value $<$ 0.05 .

\section{Hasil dan Pembahasan}

\section{Distribusi Frekuensi Atlet}

Pada penelitian ini kategori usia atlet tergolong ke dalam kategori berusia remaja madya (15-17 tahun) yakni sejumlah 34 orang (68\%). Remaja madya disebut juga masa usia krisis (age of crisis), karena diusia ini seorang anak mengalami masa pubertas. Pertumbuhan pada masa ini mengalami fisiologis yang sangat cepat. Perkembangan pada masa ini mengalami peningkatan kapasitasfungsi, kemampuan kerja organorgan tubuh, peningkatan fungsi-fungsi daya fisik, koordinasi, kontrol tubuh yang menjadikan kelincahan pada masa remaja ini meningkat. Pada masa remaja akhir, secara biologis perkembangan system reproduksi mencapai masa kematangan (11). Untuk melihat pengkategorian somatotype, bisa dilihat pada Gambar 1. Berdasarkan hasil pengukuran dapat diketahui bahwa nilai kelincahan sebagian besar atlet yaitu sebanyak 32\% dimana termasuk dalam kategori kurang. Berdasarkan pengukuran asupan karbohidrat atlet menunjukkan bahwa 54\% konsumsinya cukup. Sementara berdasarkan pengukuran somatotype atlet menunjukkan bahwa 
sebanyak 30\% termasuk ke dalamkategori central. Sementara itu, Jika dibagi dalam 3 kategori, sebanyak 34\% atlet termasuk kedalam kategori ectomorphy. Sementara itu, berdasarkan pengukuran persen lemak tubuh atlet $(34 \%)$ termasuk kedalam kategori athletic.

\section{Gambar 1.}

Chart Somatotype

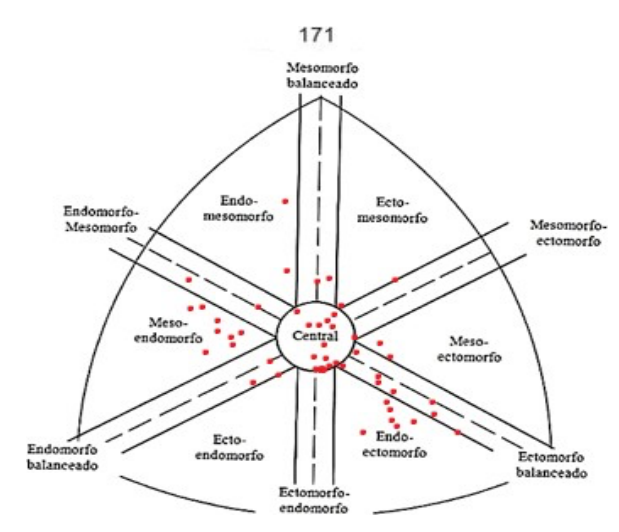

Kelincahan atlet futsal sebagian besar sejumlah 32\% berada pada kategori kurang. Jika dijumlah pada kelincahan kurang dan sangat kurang didapatkanproporsi sejumlah $40 \%$. Nilai ini melebihi proporsi dua kali lipatnya nilaikelincahan yang baik yaitu sejumlah $20 \%$. Hasil ini sejalan dengan penelitian yang dilakukan oleh Saputra, (2018) pada kelincahan atlet Salatiga Traning Center (STC) yang menyatakan bahwa nilai kelincahan dalam kategori kurang yaitu sebesar 64,7\% (4). Perbedaan hasil penelitian ini dikarenakan perbedaan dijumlah sampel, dimana penelitian Saputra (2018) mempunyai sampel sebanyak 34 orang dan hanya berusia 15- 18 tahun. Masalah kelincahan yang kurang didikarenakan, akademik always futsal baru diadakan latihan kembali di era new normal pandemi ini setelah 5 bulan lamanya diliburkan. Disaat liburan itu atlet futsal hanya berdiam saja dirumah dan minim aktifitas fisik hal ini yang memungkinkan kelincahan atlet sebagian besar pada kategori kurang (4). Penelitian menunjukkan bahwa model latihan mempengaruhi kelincahan atlit sepokbola (12).

Sementara itu untuk kategori gizi menunjukkan bahwa asupan karbohidrat tergolong cukup yaitu sebesar $54 \%$ dan yang kurang sebesar $46 \%$. Hasil ini masih lebih baik jika dibandingkan dengan penelitian yang dilakukan oleh Saputra (2018) yang menemukan bahwa proporsi atlet asupan karbohidrat yang kurang sejumlah 58,8\% (4). Hasil asupan karbohidrat yang kurang ini menunjukan bahwa kebanyakan atlet mengonsumsi karbohidrat tidak sesuai dengan kebutuhan tubuhnya masing masing. Hal ini dikarenakanatlet belum mendapatkan pengetahuan mengenai asupan karbohidrat yangsesuai dengan kebutuhan tubuhnya masing-masing, serta atlet dapat dengan bebas membeli makanan sesuai keinginannya. Penelitian kami juga sejalan dengan penelitian lain dalam cabang olahraga yang berbeda seperti olahraga basket dan olahraga hockey $(13,14)$. 
Tabel 1.

Distribusi Frekuensi Atlet

\begin{tabular}{|c|c|c|}
\hline Variable & $\mathbf{N}$ & $\%$ \\
\hline \multicolumn{3}{|l|}{ Usia (Tahun) } \\
\hline Remaja awal (12-14) & 7 & 14 \\
\hline Remaja madya (15-17) & 34 & 68 \\
\hline Remaja akhir (18-21) & 9 & 18 \\
\hline \multicolumn{3}{|l|}{ Kelincahan (detik) } \\
\hline Kurang sekali $(>19,6)$ & 4 & 8 \\
\hline Kurang $(19,0-19,6)$ & 16 & 32 \\
\hline Sedang $(18,3-19,9)$ & 9 & 18 \\
\hline Baik $(17,5-18,2)$ & 10 & 20 \\
\hline Baik sekali $(<17,4)$ & 11 & 22 \\
\hline \multicolumn{3}{|c|}{ Asupan karbohidrat (g/KgBB/hari) } \\
\hline Kurang $(<5)$ & 23 & 46 \\
\hline Cukup (5-7) & 27 & 54 \\
\hline \multicolumn{3}{|l|}{ Somatotype (13kategori) } \\
\hline Central & 15 & 30 \\
\hline Balance endomorph & 3 & 6 \\
\hline Balance mesomorph & 2 & 4 \\
\hline Balance ectomorph & 8 & 16 \\
\hline Mesomorphic endomorph & 7 & 14 \\
\hline Mesomorph endomorph & 2 & 3 \\
\hline Endomorphic mesomorph & 3 & 6 \\
\hline Ectomorphic mesomorph & 1 & 2 \\
\hline Endomorphic ectomorph & 7 & 14 \\
\hline Mesmorphic ectomorph & 2 & 4 \\
\hline \multicolumn{3}{|l|}{ Somatotype (4 kategori) } \\
\hline Central & 15 & 30 \\
\hline Endomorphy & 12 & 24 \\
\hline Mesomorphy & 6 & 12 \\
\hline Ectomorphy & 17 & 34 \\
\hline \multicolumn{3}{|l|}{ Persen Lemak Tubuh (\%) } \\
\hline Atheletic (5-10) & 17 & 34 \\
\hline Good (11-14) & 13 & 26 \\
\hline Acceptable (15-20) & 16 & 32 \\
\hline Overweight $(21-24)$ & 4 & 8 \\
\hline
\end{tabular}

Olahraga futsal termasuk ke dalam metabolism aerobic yaitu proses metabolism yang membutuhkan kehadiran oksigen (O2) dengan olahragayang bersifat ketahanan (endurance). Karbohidrat yang terdapat dalam aliran darah hanya dalam bentuk glukosa. Jika jumlah karbohidrat yang diserap tubuh melebihi kebutuhan energi tubuh, sebagian akan disimpan di dalam hatidan otot sebagai glikogen. Peristiwa oksidasi karbohidrat (glukosa di dalam jarigan terjadi secara bertingkat yang dilepaskan energi). Glukosa dan glikogen diubah menjadi asam piruvat. Asam piruvat merupakan zat penting dalam lingkaran yang dibentuk siklus trikaroboksilat (siklus asam sitrat) yang mengasilkan energi dalam bentuk ATP (adenosine tri posfat), karbondioksida (CO2) dan air (H2O) (15). Hal tersebut menjadikan asupan karbohidrat yang kurang menyebabkan energi dan kelincahan tidak maksimal. Sebaliknyajika asupan karbohidrat cukup, maka akan membuat energi dan kelincahanpada atlet maksimal. Hasil penelitian kami yang tidak signifikan bisa jadi disebabkan karena jumlah sampel yang relative tidak banyak dan konsumsi karbohidrat yang relative masih banyak yang kurang. Bahkan ini juga didukung oleh penelitian penelitian lain pada cabang olahraga dimana jumlah sampel juga tidak banyak dan konsumsinya yang masih tinggi prevalensi kurangnya.

Berdasarkan somatotype dengan 13 kategori maka sebagian besar atlet futsal di always futsal berada pada komponen somatotype yang central yaitu sebesar 30\%. Central dapat disebut seimbang yang artinya antar 
komponen somatotype tidak ada perbedaan berarti. Hal ini berbeda dengan penelitian Penggalih et al. (2016) yang menyebutkan bahwa atlet remaja sepak bola memiliki tipetubuh balanced mesomorph (5). Somatotype ini dapat disederhanakan menjadi 4 kategoridan hasilnya menunjukkan, sebagian besar pada somatotype yang ectomorph sebesar 34\% dan tidak berbeda jauh dengan somatotype yang central sebesar 30\%. Komponen ectomorphy ditandai dengan badan kurus, otot atau tungkai yang panjang dan tipis serta persentase lemak tubuh rendah. Temuan ini berbeda dengan hasilpenelitian yang dilakukan oleh Maulana (2019) dimana hasil nya menunjukkan dengan hasil rata- rata endomorphy atlet futsal sebesar 3,63 \pm 0 , mesomorphy atlet futsal


menyebutkan bahwa atlet dengan kadar lemak rendah memiliki risiko cedera yang lebih tinggi jika dibandingkan dengan tipe mesomorph dan endomorph. (18). Komponen ectomorphy ditandai dengan badan kurus, otot atau tungkai yang panjangdan tipis serta persentase lemak tubuh rendah. Tipe ini cenderung susah untuk membangun otot dan menyimpan lemak (19).

Data penelitian kami menunjukkan bahwa somatotype atlet futsal always futsal ectomorph. Komponen ectomorph ditandai dengan badan kurus, otot atau tungkai yang panjang dan tipis serta persentase lemak tubuh rendah. Endomorph ditandai dengan volumbatang tubuh cenderung besar, bentuk bulat, gemuk, persentase lemak tinggi, pinggang lebar dan struktur tulang yang besar (20). Atlet remaja sepak bola memiliki tipe tubuh balancedmesomorph (5). Komponen mesomorph ini ditandai dengan tubuh yang padat, perkembangan otot yang lebih besar, persentase lemak tubuh rendah, bahu lebar dengan pinggang yang sempit. Hal ini dikarenakan tidak adanya seleksi pada saat awal penerimaan bibit atlet baru yang ingin berlatih di always futsal. Pada persen lemak tubuh menghasilkan bahwa $40 \%$ atlet futsal memiliki persen lemak tubuh yang tergolong acceptable dan overweight didapatkan proporsi sebesar $40 \%$ dengan rata- rata persen lemak 14,2 $\pm 4,6 \%$. Hasil ini hampir sama dengan penelitian yang dilakukan Faridho (2016) dan Penggalih et al (2016) bahwa rata- rata persen lemak tubuh laki- laki adalah14.2 $\pm 3.9 \%$ dan $14.8 \pm 2.9 \%$. Rata- rata persen lemak pada atlet futsal ini masih dalam range yang dianjurkan bagi remaja laki-laki yakni 12$15 \%(16,21)$. Begitu pula dengan rata-rata persen lemak tubuh atlet sepak bola pria yang dianjurkan yakni antara $10 \%$ dan $18 \%(22)$.

\section{Hubungan Asupan Karbohidrat, Somatotype dan Persen Lemak Tubuh dengan Kelincahan}

Tabel 2 menunjukkan hubungan persen asupan karbohidrat, somatotype dan persen lemak tubuh dengan kelincahan atlet futsal Kota Bekasi. Analisis bivariat antara asupan karbohidrat dengan kelincahan menghasilkan $p$-value 0,013 yang menunjukkan hasil yang signifikan ( $p$-value $<0,05$ ). Analisis bivariat antara somatotype dengan kelincahan menghasilkan $p$-value 0,271 yang menunjukkan melebihi derajat kemaknaan yang ditetapkan yakni 0,05 . Analisis bivariat antara persen lemak tubuh dengan kelincahan menghasilkan $p$-value $0,726$ yang menunjukkan tidak signifikan ( $p$-value $>0,05)$.

Tabel 2.

Analisis bivariat

\begin{tabular}{|c|c|c|c|}
\hline \multicolumn{4}{|c|}{ Analisis bivariat } \\
\hline \multirow{2}{*}{ Asupan karbohidrat } & \multicolumn{2}{|c|}{ Kelincahan } & \multirow{2}{*}{$p$-value } \\
\hline & Tidak lincah & Lincah & \\
\hline Kurang & 9 & 14 & \multirow{2}{*}{0,013} \\
\hline Cukup-lebih & 20 & 7 & \\
\hline \multirow{2}{*}{ Somatotype } & \multicolumn{2}{|c|}{ Kelincahan } & \multirow{2}{*}{$p$-value } \\
\hline & Tidak lincah & Lincah & \\
\hline Tidak sesuai & 17 & 9 & 0,271 \\
\hline Sesuai & 12 & 12 & \\
\hline \multirow{2}{*}{ Persen lemak tubuh } & \multicolumn{2}{|c|}{ Kelincahan } & \multirow{2}{*}{$p$-value } \\
\hline & Tidak lincah & Lincah & \\
\hline Tidak sesuai & 11 & 9 & 0,726 \\
\hline Sesuai & 18 & 12 & \\
\hline
\end{tabular}

\section{Hubungan asupan karbohidrat dan kelincahan}

Hubungan antara asupan karbohidrat dengan kelincahan menunjukkan bahwa atletfutsal di always futsal mempunyaikelincahan pada kategori tidak lincah, dengan proporsi yang lebih besar yaitu 58\%. Sementara itu untuk asupan karbohidrat menunjukkan bahwa mereka yang lincah yaitu pada kategori 
kurang sebesar 39,1\% dibandingkan dengan kategori cukup-lebih yaitu sebesar 74,1\%. Hasil ujistatistic menghasilkan $p$-value 0,013 , kurang derajat kemaknaan yangditetapkan yakni 0,05 . Hasil penelitian ini sejalan dengan penelitian Hosianna (2017) yang menyatakan bahwa semakin tinggi asupan karbohidrat maka semakin meningkat kelincahan (23). Pada penelitian yang dilakukan oleh Mujika etal (2010) menemukan bahwa setelah pemberian asupan makan tinggi karbohidrat terjadi pengingkatan kemampuan dribbling dan shooting pada atlet sepak bola (24). Hal ini kemungkinan terjadi karena deplesi glikogen yang mungkin terjadi saat asupan makan kurang dari kebutuhan tidak mengurangi kemampuanketerampilan atlet. Asupan zat gizi yang optimal selama olahraga dan aktivitassangat penting untuk menyediakan cadangan energi yang digunakan sebagai bahan bakar selama berolahragasehingga atlet tidak mudah lelah. Hubungan antara somatotype dengan kelincahan dari hasil uji Chi square menghasilkan bahwa atlet futsal yang memiliki kelincahan dengan kategori tidak lincah dibandingkan dengan kategori yang sesuai. Hasil uji statistik menghasilkan $p$-value 0,271 melebihi derajat kemaknaan yang ditetapkan yaitu 0,05.

Komponen ectomorph ditandai dengan badan kurus, otot atau tungkai yang panjang dan tipis serta persentase lemak tubuh rendah. Mesomorph ditandai dengan tubuh yang padat, perkembangan otot yang lebih besar, persentase lemak tubuh rendah, bahulebar dengan pinggang yang sempit. Endomorph ditandai denganvolum batang tubuh cenderung besar, bentuk bulat, gemuk, persentase lemak tinggi, pinggang lebar dan struktur tulang yang besar (20). Hasil penelitian ini sejalan dengan penelitian Hosianna (2017) yang menyatakan melebihi derajat kemaknaan antara somatotype dengan kelincahan (23). Hasil penelitian ini sejalan dengan penelitian yang dilakukan oleh Saputra, (2018) yang meyatakan nilai $\mathrm{p}=0,092$ melebihi derajat kemaknaan yaitu 0,05 (4). Sama halnya juga dengan hasil penelitian Qurun (2016) yang menyatakan bahwa antara somatotype dengan kelincahan nilai $p$ melebihi derajat kemaknaan (25). Bentuk tubuh yang sesuai dengan cabang olahraga yang digeluti akan berpengaruh positif bila disesuaikan dengan aktivitas yang dilakukan guna mencapai hasil kerja maksimal (16). Lee dan Lin (2007) menyebutkan bahwa ukuran dan struktur tubuh adalah sesuatu yang sangat mempengaruhi penampilan dalam olahraga. Tipe tubuh atlet sepak bola berkaitan dengan kecepatan,kelincahan, dan kontak tubuh (8).

Hasil penelitian kami menunjukkan bahwa tidak ada hubungan antara persen lemak tubuh dengan kelincahan dengan $p$-value $>0,05$. Hasil penelitian ini sejalan dengan penelitian yang dilakukan oleh Saputra (2018) yang meyatakan nilai $\mathrm{p}=0,066$ melebihi derajat kemaknaan yang ditetapkan yakni 0,05 (4). Hal ini juga sejalan dengan penelitian Narruti (2012) yang menyatakan nilai p melebihi derajat kemaknaan yang ditetapkan yakni 0,05 (27). Menurut Esco et al., (2018) kelebihan lemak pada tubuh dapat menghambat kinerja otot dan gerakan lambat pada atlet muda $(10,28)$. Terlepas dari ukuran tubuh, persen lemak tubuh yang lebih tinggi juga dapat menurunkan kemampuan untuk mempertahankan serangan intermiten berulang dari latihan intensitas tinggi selama durasi pertandingan (11). Di sisi lain, persen lemak tubuh yang lebih rendah dapat dikaitkan dengan kelelahan yang tertunda dan memungkinkan kemampuan untuk mempertahankan aktivitas aerobik dan anaerobik gabungan dari permainan futsal untuk durasi yang lebih lama $(10,28)$.

\section{Kesimpulan}

Kelincahan seorang atlet sangat dipengaruhi oleh asupan makananya. Tingkat kecukupan karbohidrat atlet always futsal berhubungan dengan kelincahan. Atlet always futsal perlu memperbaiki asupan karbohidratnya yang masih belum memenuhi standar minimal.

\section{Daftar Pustaka}

1. Ismaryati. Peningkatan Kelincahan Atlet melalui Penggunaan Metode Kombinasi Latihan Sirkuit pliometrik dan Berat Badan. J Paedagog. 2008; 11: 74-89.

2. Rahmaniar A, Dewi RC. Tingkat Konsumsi Karbohidrat, Status Hidrasi dan Tingkat Kelincahan pada Atlet Basket Remaja. Amerta Nutrition, 2018; 2(2): 197-204.

3. William. Nutrition for Health, Fitness and Sport. New York: Eleven Edition; 2021.

4. Saputra, R. P. S., Tursilowati, S., Larasati, M. D., \& Sunarto, S. (2019). Hubungan Asupan Lemak, Persen Lemak Tubuh, Somatotype Dengan Kelincahan Atlet Sepakbola Diklat Salatiga Training Centre (Stc). Jurnal Riset Giri, 7(1), 21-27.

5. Tóth T, Michalíková M, Bednarčíková L, Živčák J, Kneppo P. Somatotypes in sport. Acta mechanica et automatica, 2014; 8.

6. Lukaski HC. Body composition: health and performance in exercise and sport. CRC Press; 2017.

7. Thygerson AL, Thygerson SM, Thygerson JS. Fit to be Well. Jones \& Bartlett Learning; 2021 
8. Mayorga-Vega D, Aguilar-Soto P, Viciana J. Criterion-related validity of the 20 -m shuttle run test for estimating cardiorespiratory fitness: a meta-analysis. Journal of sports science \& medicine. 2015; 14(3): 536.

9. Gibson RS. Principles of nutritional assessment. Oxford university press; 2015.

10. Carter JEL. The heath-carter anthropometric somatotype. 2012

11. Hamali S. Karakteristik Keberagamaan Remaja Dalam Perspektif Psikologi. Al-Adyan: Jurnal Studi Lintas Agama. 2016; 11(1): 81-98.

12. Anis J. Pengaruh Model Latihan Dan Motivasi Terhadap Peningkatan Kelincahan Atlet Club Futsal Nusantara Jakarta Timur. Jurnal Bola. 2018; 1(1): 65-72.

13. Rahmaniar A, Dewi RC. Tingkat Konsumsi Karbohidrat, Status Hidrasi dan Tingkat Kelincahan pada Atlet Basket Remaja. Amerta Nutrition, 2018; 2(2): 197-204.

14. Gifari N, Purwaningtyas DR. Hubungan Status Gizi, Asupan Energi Dan Zat Gizi Terhadap Kecepatan Dan Kelincahan Peserta Ekstrakurikuler Hoki Sman Di Kabupaten Tangerang. Jurnal Gizi Dan Kesehatan. 2021; 13(1): 124-142.

15. Yustika GP. Peranan Karbohidrat dan Serat Pangan untuk Pemain Sepakbola. Jurnal Media Ilmu Keolahragaan Indonesia. 2018; 8(2): 49-56.

16. Penggalih MHS. Efektivitas penatalaksanaan gizi pada atlet terhadap perbaikan status gizi sebagai penunjang performa (Kajian pada atlet sepak bola remaja). Univ Gadjah Mada [Internet]. 2017; Available from: http:/ / etd.repository.ugm.ac.id/index.php?mod=penelitian_detail\&sub=Penel itianDe tail\&act=view\&typ=html\&buku_i d $=1118$ 28\&obyek_id $=4$

17. Maulana WG. Perbedaan Somatotype Atlet Futsal V amos FC Mataram dan Atlet Basket Bima Perkasa Jogja. JOSSAE (Journal of Sport Science and Education). 2020; 4(2): 63-68.

18. Kemper GLJ, Van Der Sluis A, Brink MS, Visscher C, Frencken WGP, Elferink-Gemser MT. Anthropometric injury risk factors in elite-standard youth soccer. International Journal Of Sports Medicine. 2015; 36(13): 1112-1117.

19. Patwardhan B, Mutalik G, Tillu G. Integrative approaches for health: Biomedical research, Ayurveda and Yoga. Academic Press; 2015.

20. Vertinsky P. Physique as destiny: William H. Sheldon, Barbara Honeyman Heath and the struggle for hegemony in the science of somatotyping. Canadian Bulletin Of Medical History. 2007; 24(2): 291-316.

21. Faridho Z. Analisis Karakteristik. Antropometri dan Komposisi Tubuh dengan Somatotype Atlet Remaja Sekolah Atlet Ragunan Jakarta. Institut Pertanian Bogor: 2016.

22. Jeukendrup A, \& Gleeson, M. (2010). An introduction to energy production and performance. Sport Nutrition-2nd Edition. ISBN-13: 9780736079624.

23. Hosianna DC HM. Hubungan Asupan Zat Giz̧i Makero dan Somatotype terhadap Kelincahan Pemain Sepakbola Unit Kegiatan Mahasiswa (UKM) di Daerah Istimewa Yogyakarta. 2017; 2-3.

24. Mujika I, Burke LM. Nutrition in team sports. Annals of Nutrition and Metabolism. 2010; 57(Suppl. 2): 26-35.

25. Qurun DK. Hubungan Somatotype dengan Kelincahan Atlet Sepak Takraw UPT SMA Negeri Olahraga Jawa Timur. Dep Antropol Fak Ilmu Sos dan Ilmu Polit Univ Airlangga, Surabaya. 2016;5(2): 232- 8.

26. Lee AJ, Lin WH. The influence of gender and somatotype on single-leg upright standing postural stability in children. Journal Of Applied Biomechanics. 2007; 23(3): 173-179.

27. NH N. Hubungan Asupan Lemak, Persentase Lemak Tubuh, Somatotype Dengan Kelincahan Atlet Pencak Silat Kategori Latih Tanding Pelatihan Daerah (PELATD A) Daerah Istimewa Yogyakarta. Skripsi Gizi Kesehat Univ Gajah Mada. 2012.

28. Esco M, Fedewa M, Cicone Z, Sinelnikov O, Sekulic D, Holmes C. Field-based performance tests are related to body fat percentage and fat-free mass, but not body mass index, in youth soccer players. Sports. 2018; 6(4): 105

29. Krustrup P, Bradley PS, Christensen JF, Castagna C, Jackman S, Connolly L, Bangsbo J. The Yo-Yo IE2 test: physiological response for untrained men versus trained soccer players. Medicine And Science In Sports And Exercise. 2015; 47(1): 100-108. 